\title{
Testing the pecking order theory of capital structure: the case of Islamic financing modes
}

\author{
Moncef Guizani*
}

\begin{abstract}
The purpose of this paper is to examine whether or not the basic premises according to the pecking order theory provide an explanation for the capital structure mix of firms operating under Islamic principles. Pooled OLS and random effect regressions were performed to test the pecking order theory applying data from a sample of 66 Islamic firms listed on Kingdom of Saudi Arabia stock market over the period 2006-2016. The results show that sale-based instruments (Murabahah, ljara) track the financial deficit quite closely followed by equity financing and as the last alternative to finance deficit, Islamic firms issue Sukuk. In the crisis period, these firms seem more reliant on equity, then on sale-based instrument and on Sukuk as last option. The study findings also indicate that the cumulative financing deficit does not wipe out the effects of conventional variables, although it is empirically significant. This provides no support for the pecking order theory attempted by Saudi Islamic firms. This research highlights the capital structure choice of firms operating under Islamic principles. It explores the implication of the relevant Islamic principles on corporate financing preferences. It can serve firm executive managers in their financing decisions to add value to the companies.
\end{abstract}

Keywords: Pecking order theory, Capital structure, Murabahah, ljara, Sukuk, Islamic-compliant firms

\section{Introduction}

Making financing decisions for firms is one of the most fundamental topics in contemporary finance research since the influential studies of Modigliani and Miller [26] on capital structure irrelevancy. Once we move away from a model of perfect capital markets, most theories have sought to explain how companies choose a particular combination of debt and equity by introducing frictions omitted in the original Modigliani and Miller framework. The pecking order theory (POT) is among the most influential theories of capital structure.

Pioneered by Myers [28] and Myers and Majluf [29], pecking order refers to managers' preferences for funding sources to cover their financing needs. The theory states that managers prefer internal to external financing, and, when outside funds are necessary, they prefer debt to equity because of lower information costs associated

\footnotetext{
*Correspondence: guizani_m@yahoo.fr

College of Science and Humanity Studies in Sulayel, Prince Sattam Bin Abdulaziz University - Kingdom of Saudi Arabia, Al-Kharj, Saudi Arabia
}

with debt issues. They issue equity as the last alternative. Managers follow this financing hierarchy behavior to avoid both the wealth transfer to outsiders and the negative effect of adverse selection inherent to external funding sources.

In the last two decades, the business community had witnessed a drastic growth of Islamic funds all over the world. Islamic finance has attracted a fair amount of attention from stock market participants. The financial market around the world experienced exceptional growth in Islamic finance [30]. In addition, the recent global financial crisis has added further to the attraction of Islamic finance to practitioners, monetary authorities and academic scholars in their search for a viable and resilient alternative financial system [17]. This increasing market share of Islamic banking begs the question of the importance of Islamic financing instruments in firms' financing choice.

Islamic firms consider Islamic business principles crucial to their business operations. They would not engage in any activity which is forbidden by Islam. For example, 
no firm in an Islamic society would be operating in the production or sale of alcoholic drinks or the production or sale of pigs, or gambling or forbidden speculation, or in lending or borrowing money at fixed interest rates. By reviewing the main restrictions, one can understand how these restrictions might alter Islamic firms' capital structure decisions.

Limited research has been conducted in the areas of financing hierarchy of Islamic financial instruments. Kayed [19] argues that the dominant modes of finance that are being practiced by the majority of Islamic financial institutions are risk-free financing schemes such as Murabahah and Ijara. In a similar vein, Ismal [18] finds that Murabahah financing in the Indonesian Islamic banking industry is the most favored form of Islamic financing. Such a contract dominates $56.24 \%$ the total Islamic financing, followed by Mudarabah financing (18.54\%) and Musharakah financing (9.76\%). Sakti et al. [33] suggest that the presence of less asymmetric information and lower agency costs between shareholders and managers lead Islamic banks to opt for equity financing. However, lower bankruptcy costs and lower agency costs between shareholders and debt holders lead Islamic banks to favor debt-based financing. Miah and Suzuki [24] show that about $90 \%$ of the total financing in GCC countries are concentrated on Murabahah, which is the result of existing institutional underpinnings. GCC Islamic banks are involved with PLS-based financing only limitedly.

Thus, in light of the above, it is worth exploring the implications of the relevant Islamic principles on the Islamic firms' capital structure choice. In particular, this study sheds light on whether the basic premises according to the POT provide an explanation for the capital structure mix of KSA Islamic firms.

KSA is an interesting case for studying the financing hierarchy of Islamic financial instruments. Most Saudi listed firms, with their compliance to Sharia rules, are thus differentiated from their conventional counterparts. The legal system of KSA is based on Islamic law (Sharia) derived from the Qur'an and the Sunnah (the traditions of the Islamic prophet Muhammad), which prohibits loan interests whether giving or taking.

This study contributes to existing literature in two ways. First, it highlights the capital structure choice of firms operating under Islamic principles. It explores the implication of the relevant Islamic principles on the financing preferences of KSA firms. Due to the prohibition of interest on debt and promotion of profit and loss sharing, Islamic financing invokes a question on whether the corporate capital structure choice will be influenced by a set of factors similar to conventional finance. Second, the present paper provides further evidence on the impact of financial crisis on the firms' capital structure choice in a period of considerable slowdown in the world. The credit shortages that characterize the last financial crisis have resulted in changing of firms' demand for credit. This has raised the role of Islamic-based financing as a substitution for the conventional finance system [35]. Therefore, given the high penetration of Islamic finance against conventional finance in KSA, this study provides insights into how the contraction of bank lending during the 2008-2009 crisis affects the corporate capital structure choice in an Islamic finance setting.

Following this introductory section, the rest of the study is organized as follows: "Literature review" section discusses the costs of financial instruments and reviews existing studies in the literature. "Data and methodology" section discusses the data and the theoretical framework. "Results and discussion" section presents the empirical findings, while "Conclusion" section concludes with policy implications.

\section{Literature review \\ Cost structure of Islamic financial instruments}

Islamic financial instruments are based on the principles that they exclude interest (riba), not possess major uncertainty (gharar) and not have gambling like features (Maysir). Under these principles, Islamic modes of financing can be broadly classified into sale-based, profitloss sharing (PLS) and hybrid instruments. Sale-based instruments are fixed-income instruments that replicate the payoff of a debt instrument by applying the sum paid in advance plus a predefined mark-up. They include: Murabahah, Salam, Istisna and Ijara. PLS instruments are Islamic participation contracts based on the principle of profit and loss sharing. They include: Mudarabah and Musharakah. Hybrid instruments have the characteristics of both, sale-based and PLS instruments. They include Sukuk. ${ }^{1}$

Islamic financial contracts may generally involve direct and indirect costs. To quantify different costs, we follow Ahmed [1] by ranking them as high, medium, low and negligible. The following table summarizes the cost structure of different financial instruments (Table 1).

Murabahah and Ijara are considered as debt-based instruments having low risk relative to equity-based instruments. Accordingly, they have the lower cost of funds. Given that they are negotiated with financial institutions, their contracting costs are relatively low and they imply no floatation costs as in case of

\footnotetext{
1 The AAOIFI Sharia Standard (17) defines Sukuk as being: "Certificates of equal value representing undivided shares in the ownership of tangible assets, usufructs and services or (in the ownership of) the assets of particular projects or special investment activities."
} 
Table 1 Costs of various Islamic financial instruments

\begin{tabular}{|c|c|c|c|c|c|c|}
\hline \multirow[t]{2}{*}{ Instruments } & \multicolumn{2}{|c|}{ Direct costs } & \multicolumn{3}{|c|}{ Indirect costs } & \multirow[t]{2}{*}{ Total costs } \\
\hline & Funds & Contracting/floatation & Dilution & Distress & Information & \\
\hline \multicolumn{7}{|l|}{ Debt-based } \\
\hline Murabahah & $L(=1)$ & $L(=1)$ & $N(=0)$ & $M(=2)$ & $N(=0)$ & 4 \\
\hline ljara & $L(=1)$ & $L(=1)$ & $N(=0)$ & $M(=2)$ & $N(=0)$ & 4 \\
\hline \multicolumn{7}{|l|}{ Equity-based } \\
\hline Mudarabah & $M(=2)$ & $M(=2)$ & $M(=2)$ & $N(=0)$ & $H(=3)$ & 9 \\
\hline Musharakah & $H(=3)$ & $H(=3)$ & $H(=3)$ & $N(=0)$ & $M(=2)$ & 11 \\
\hline \multicolumn{7}{|l|}{ Hybrid } \\
\hline Sukuk & $L(=1)$ & $M(=2)$ & $L(=1)$ & $M(=2)$ & $H(=3)$ & 9 \\
\hline
\end{tabular}

$H$ high (with value 3), $M$ medium (with value 2 ), $L$ low (with value 1 ) and $N$ negligible (with value 0 )

securities [1]. As financing techniques, Murabahah and Ijara involve no ownership dilution, and thus, their dilution costs are negligible. In addition, since the bank holds the ownership of the asset, these contracts would reduce the problems of asymmetric information associated with financing to more opaque borrowers. Under contracts such as Murabahah and Ijara, the rate of return is fixed and predetermined and adverse selection and moral hazard problems would not arise. In contrast, as they are debt-based instruments, they have inherent distress costs.

With respect to equity-based instruments, they are based on the principle of profit and loss sharing. Their costs of funds are relatively high. However, given that Mudarabah contracts are not affected by dividend policy, their cost of funds will be smaller than the Musharakah contracts. Moreover, their floatation costs will be relatively lower than those for Musharakah contracts. On the other hand, a firm will choose Mudarabah instead of Musharakah contract to avoid ownership dilution. Mudarabah is a PLS contract where the ownership of the capital or invested assets remain with the fund provider at all times and the entrepreneur provides effort and management expertise. In contrast, the Musharakah contract involves a partnership where both partners, that is, entrepreneur and investor jointly provide the capital and manage the venture. In addition, PLS contracts are inherently vulnerable to asymmetric information problems. These problems are relatively higher in the case of Mudarabah contract. Asymmetric information on Mudarabah contract arises because the entrepreneur who manages the Mudarabah fund has full control of the project and has more information regarding the project, which the capital provider does not usually have access to. Consequently, two major problems are issued from the inefficiency in information delegation: adverse selection and moral hazard problems.
As for Sukuks, they are considered as hybrid securities, bearing the features of stocks and bonds. Similar to a bond, Sukuk has a maturity date and some of these securities are usually of fixed revenue and a final payment at the maturity date [37]. Sukuk holders have recourse to the assets in the event of default, or if the issuers have difficulty in repaying. This involves that they have low cost of funds. In addition, given their tradability in secondary market, Sukuks are liquid instruments, which involve a medium low floatation costs. On the other hand, although the Sukuks are indicative of some sort of partnership and ownership of the holder in respect of the asset, they lack right of voting and interfering in underlying asset. These Islamic instruments involve a high information cost. Due to their specific structuring, Sukuks are especially exposed to moral hazard and adverse selection problems [21].

\section{The empirical findings of the POT: conventional versus Islamic-compliant firms}

There has been an intense debate over the capital structure choice for conventional firms, particularly in the recent literature. In spite of an enormous volume of research, the hierarchy or pecking order among different sources of funds remains equivocal. One branch of research has provided evidence that is consistent with managers' pecking order preference. Shyam-Sunder and Myers [34] find that the pecking order model is an excellent first-order descriptor of financing behavior in US firms. Booth et al. [6] find result in favor of the POT in developing countries. In the same vein, Lemmon et al. [23] find evidence in tune with the POT. After controlling for debt capacity, the authors show that firms' financing behavior follows the financing hierarchy described by the pecking order model.

However, other empirical studies have found no support of the POT predictions. For instance, Frank and 
Goyal [14] find results that are surprising from the perspective of the POT. Using a sample of US firms, the authors show that debt financing does not dominate equity financing in magnitude. The evidence provided by Fama and French [13] strongly rejects the POT hypothesis. They reveal that firms heavily rely on equity financing to fill up deficiency needs. Komera and Lukose [22] argue that the POT fails to explain Indian firms' financing choices. Their estimated annual pecking order coefficients show no support for the financing choices described by the POT. Allini et al. [2] support the predictions of a modified POT in Egypt. They identify that internally generated funds are the preferred option for Egyptian firms followed by equity, where a financial deficit is present, and finally debt finance as a last resort.

In spite of Sharia restrictions on interest, little is known about how these restrictions translate into capital structure decisions in Islamic countries. Using sample of firms in Islamic and non-Islamic countries, Gunn and Shackman [15] provide evidence that Islamic law does not disadvantage firms in terms of the overall levels of debt compared to equity financing. The findings reveal no difference in the level of total debt to total assets when comparing capital structure in firms from Islamic countries to firms in non-Islamic countries. Minhat and Dzolkarnaini [25] addressed the question of which firms use Islamic financing. They provide evidence that Islamic financing attracts less profitable firms due to the presence of adverse selection among Islamic financiers. Yildirim et al. [36] compared the key capital structure determinants between Sharia-compliant (SC) and non-Sharia-Compliant (NSC) firms. Due to the restrictions imposed by Sharia rules, it is expected that SC firms exhibit different capital structure compared to their NSC peers. Their results show that most of the determinants do exhibit different effects among both firm types. The authors document that capital structure decisions for SC and NSC firms are better explained by the pecking order for book leverage and by the trade-off theory for market leverage. In the same token, Alnoria and Alqahtani [3] investigate the effect of Sharia-compliance status on firms' capital structure decisions in non-financial firms in the KSA market. They find that SC firms have significantly lower levels of leverage and slower speeds of adjustment than NSC firms. The authors explain these findings by the financing restrictions to which SC firms are subject, creating a finance supply gap for these firms and higher adjustment costs.

\section{Data and methodology Data sources and sample}

The study sample consists of non-financial companies that are publicly traded on the KSA stock exchange.
The analysis is about the period from 2006 to 2016 . The financial and market data used in this research were hand-collected from listed firms' annual reports provided by the website https://www.argaam.com. We exclude financial firms (banks and insurance) due to their specific regulations. We also exclude firms with missing information over the study period.

This study follows the Sharia Guidelines of Alrajhi bank for Trading and Investment in Stocks. The Sharia Board of Alrajhi Bank has issued its resolution No. (485) regarding the legal rule on the investment and trading in the stocks of the joint stock companies, as follows:

Joint stock companies, in terms of their objectives, activities and controls of dealing in their stocks, are classified into three types:

(1) Joint stock companies with permissible objectives and activities;

(2) Joint stock companies with illicit objectives and activities (e.g., tobacco, pork, gambling, interestbearing banking activities);

(3) Companies whose objectives and activities are permissible but may have illicit matters in their dealings, such as dealing in usurious interest-bearing loans or deposits.

According to this classification, we define Islamic firms as those of type one. These firms use non-interest based financing modes to finance their assets.

Table 2 describes the sample selection procedure. The final sample consists of 66 firms with a total of 726 firmyear observations.

\section{Theoretical framework and measures of variables}

This study employs the methodology of Shyam-Sunder and Myers [34] and Frank and Goyal [14] to test the POT. The test advanced by the authors is based on the implication that, under the POT, a substantial amount of inter-temporal variation in net debt issue $(\Delta \mathrm{D})$ should be explained by a single variable, the funds flow deficit (DEF). The DEF variable is given by the following identity:

$$
\mathrm{DEF}_{t}=\mathrm{DIV}_{t}+I_{t}+\Delta W_{t}-C_{t}=\Delta D_{t}+\Delta E_{t}
$$

where $\operatorname{DIV}_{t}$ : cash dividends in year $t ; I_{t}$ : net investment in year $t ; \Delta W_{t}$ : change in working capital in year $t$; $C_{t}$ : cash flows after interest and taxes in year $t ; \Delta D_{t}$ : net debt issued in year $t ; \Delta E_{t}$ : net equity issued in year $t$.

According to Shyam-Sunder and Myers [34], the testing strategy of the pecking order hypothesis relies on the following simple model: 
Table 2 Summary of the sample selection procedure

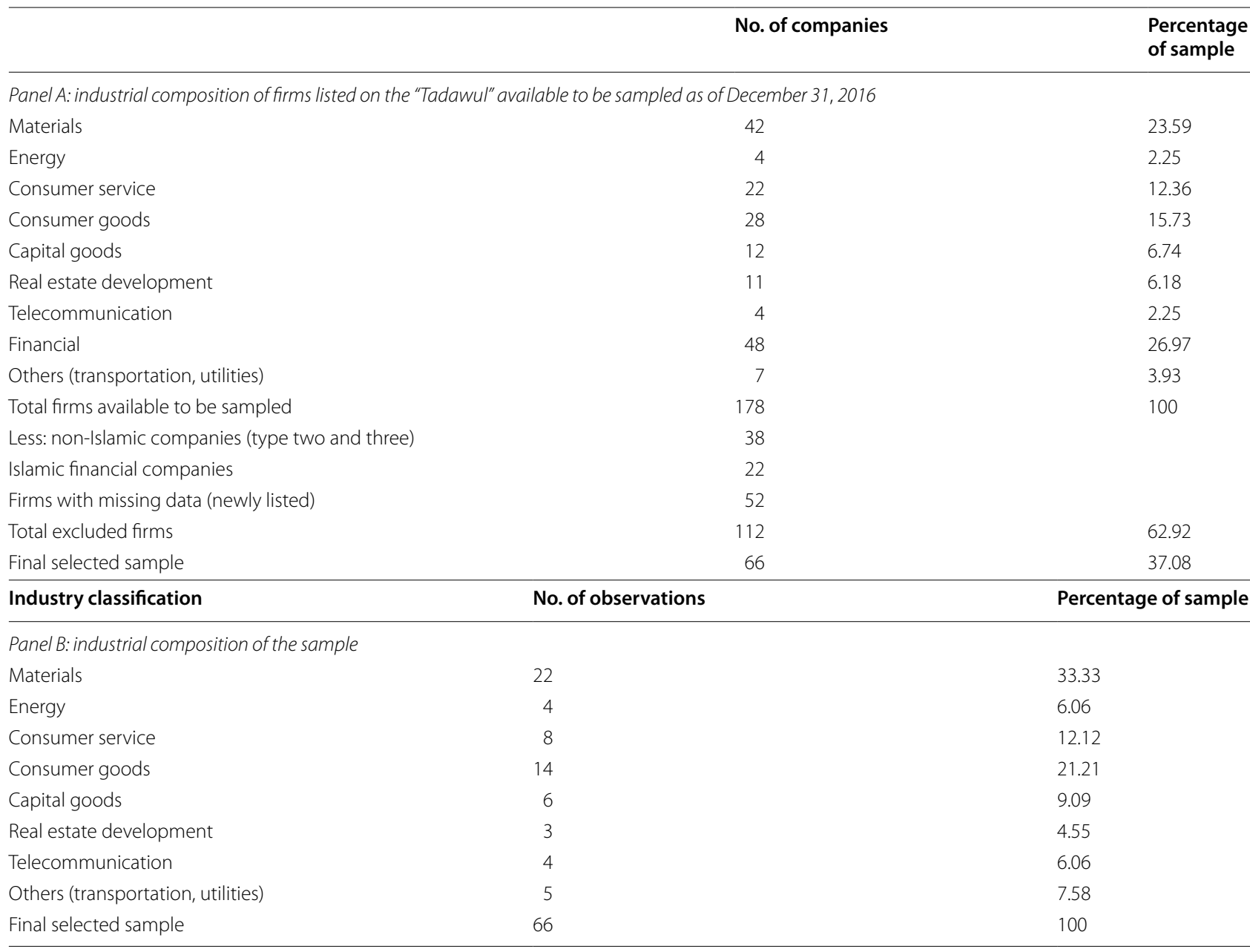

$$
\Delta D_{i, t}=\alpha_{\mathrm{po}}+\beta_{\mathrm{po}} \mathrm{DEF}_{i, t}+e_{i, t}
$$

where $\alpha_{\mathrm{po}}$ and $\beta_{\mathrm{po}}$ are the pecking order parameters and $e_{i, t}$ is an error term. In Eq. (2), the strong form test of the pecking order model predicts that $\alpha_{\mathrm{po}}=0$ and $\beta_{\mathrm{po}}=1$ [34]. However, according to Chirinko and Singha [9], the later form is very restrictive and therefore will not be very useful in evaluating the pecking order model. The authors propose a semi-strong form, which states that firms meet their deficit-in-funds by relying initially and primarily on debt finance.

Given the characteristics of Islamic financial instruments, we propose the following models:

$$
\mathrm{NDI}_{i, t}=\alpha_{\mathrm{po}}+\beta_{\mathrm{po}} \mathrm{DEF}_{i, t}+e_{i, t}
$$

where NDI is net debt issued (Murabahah, Ijara).

$$
\mathrm{NSKI}_{i, t}=\alpha_{\mathrm{po}}+\beta_{\mathrm{po}} \mathrm{DEF}_{i, t}+e_{i, t}
$$

where NSKI is net Sukuk issued.

Because of the presence of debt capacity constraints, firms must resort to equity issues. Following Chirinko and Singha [9] argument, the present study uses Eq. (5) below to be compared with Eqs. (3) and (4).

$$
\mathrm{NQI}_{i, t}=\alpha_{\mathrm{po}}+\beta_{\mathrm{po}} \mathrm{DEF}_{i, t}+e_{i, t}
$$

where NQI is net equity issued.

Moreover, to test the predictions of the POT in KSA context, the present paper refers to the modified conventional regression of leverage of Frank and Goyal [14]. In the following regression equation, the cumulative financing deficit (CDEF) replaces the financing deficit (DEF) because of using levels of leverage rather than changes in leverage [8].

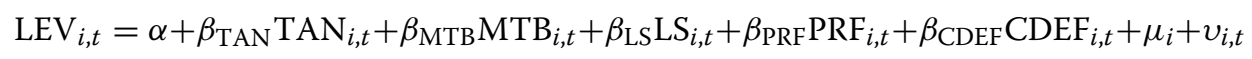


Table 3 Descriptive statistics

\begin{tabular}{lllll}
\hline Variables & Mean & STD & Min & Max \\
\hline DEF & 0.055 & 0.205 & -1.734 & 1.252 \\
NDI & 0.014 & 0.082 & -0.314 & 0.755 \\
NSKI & 0.002 & 0.028 & -0.095 & 0.326 \\
NQI & 0.009 & 0.161 & -4.453 & 0.626 \\
BBD & 0.271 & 0.468 & 0 & 0.897 \\
MBD & 0.257 & 0.772 & 0 & 0.949 \\
MTB & 1.928 & 1.032 & 0.731 & 6.675 \\
LS & 9.333 & 0.715 & 7.731 & 11.531 \\
TAN & 0.577 & 0.204 & 0.021 & 0.974 \\
PRF & 0.091 & 0.099 & -0.509 & 1.103 \\
\hline
\end{tabular}

where LEV refers to book leverage (long-term debt/total assets) or market-based debt (long-term debt to market capitalization), TAN is the tangibility of assets (fixed assets/total assets), MTB is the market-to-book ratio (the ratio of the sum of the market value of equity and the book value of debt to the book value of assets), LS is the size of the firm (log of assets), PRF is the profitability (operating income/total assets), and CDEF is the cumulative financing deficit (the ratio of cumulative financing deficit to the book value of assets). $\left(\mu_{\mathrm{i}}\right)$ is the unobservable individual heterogeneity, and $\left(v_{i, t}\right)$ is the remainder disturbance or the usual disturbance in the regression model that varies with individual units and time. According to Frank and Goyal [14], the pecking order predicts that $\beta_{\mathrm{TAN}}<0, \beta_{\mathrm{MTB}}<0, \beta_{\mathrm{LS}}>0, \beta_{\mathrm{PRF}}<0$, and $\beta_{\mathrm{CDEF}}>0$.

Equation (6) is simply a modified conventional regression with cumulative financing deficit as an added factor. If the inclusion of the cumulative financial deficit variable should wipe out the effect of the other variables, then the predictions of the POT would be supported. Otherwise, the predictions of the POT would be contradicted $[2,14]$.

\section{Results and discussion Descriptive statistics}

Table 3 provides the main summary statistics for the variables used in the empirical analysis. Interestingly, to track their financing deficit, KSA firms first issue debtbased instruments (Murabahah, Ijara), then equity, and finally they issue $S u k u k$ as a last resort. On average, the net debt issued is $1.4 \%$ of total assets higher than $0.9 \%$ of net equity issued and $0.2 \%$ of net Sukuk. This suggests the preference of KSA firms to issue debt-based instruments rather than equity and Sukuk.

The average values of book-based debt and marketbased debt are $27.1 \%$ and $25.7 \%$, respectively. Looking at these results in comparison with those in other developing and developed countries, Allini et al. [2] find that the book-based debt and market-based debt means in Egypt are 17\%, and 14\%, respectively. Chen et al. [8] find them to be $39 \%$ and $35 \%$ in Taiwan. In European context, Moradi and Paulet [27] find a book-based debt mean of 26\% in Austria, 23\% in Belgium, 20\% in France, $21 \%$ in Germany, $20 \%$ in Luxembourg and $26 \%$ in Netherlands.

With regard to other variables, the results show a mean value of market-to-book ratio of 1.928 , with a range from 0.731 to 6.675 . The tangible assets as a percentage of total assets average $57.7 \%$. The average firms' size measured by the log of total assets is about 9.333. The KSA firms' profitability averages $9.1 \%$ and ranges between $-50.9 \%$ and $110.3 \%$

\section{Tests of pecking order of Islamic financial instruments}

Consistent with previous works [9, 34], this study seeks to examine how well Islamic financial instruments track the financing deficit.

The selection of the appropriate model was made following four different tests developed by Baltagi [5], Chow [10], Hausman [16], and Breusch and Pagan [7]. The $F$ test [5] determines the best model between pooled OLS and the alternatives of panel data (i.e., fixed and random effects, respectively). A Chow test was performed to distinguish between the pooled OLS model and the fixed effect model. The Breusch and Pagan Lagrangian multiplier (LM test) was performed to examine the existence of random effects. The Hausman test is used to select the best model between the random effects model and the alternative fixed effects model.

The results of the $F$ test, Chow test and Breusch and Pagan test (Tables 4 and 5) reveal that the pooled OLS estimators are the most appropriate. The statistics of these tests are not significant.

Table 4 summarizes the basic ordinary least squares (OLS) tests. The dependent variables are net debt (Murabahah, Ijara) issued, net Sukuk issued, total debt issued and net equity issued, all scaled by book assets. The results show that the constant, $\alpha$, is close to zero in all regressions. The slope parameter, $\beta$, ranges from 0.071 to 0.614 depending on the dependent variable. Interestingly, it seems that sale-based instruments (Murabahah, Ijara) track the financial deficit much closer as they are cheaper than other alternatives and they do not dilute ownership. The estimated coefficient on financial deficit as 0.543 is still far below from observed coefficient for conventional firms in the US market, that ranging between 0.75 and 0.85 [34]. However, it is still far above from observed coefficients in Egyptian market and Taiwan market that are 0.340 and 0.309 , respectively $[2,8]$. 
Table 4 The estimators for pecking order model for the full sample

\begin{tabular}{lllll}
\hline & $\begin{array}{l}\text { Net debt issued } \\
(\mathbf{1})\end{array}$ & $\begin{array}{l}\text { Net Sukuk issued } \\
(\mathbf{2})\end{array}$ & $\begin{array}{l}\text { Total debt issued } \\
\text { (3) }\end{array}$ & $\begin{array}{l}\text { Net equity issued } \\
(\mathbf{4})\end{array}$ \\
\hline$a$ & $0.006^{* * *}$ & 0.001 & $0.008^{* * *}$ & 0.009 \\
$\beta$ & $(3.61)$ & $(1.48)$ & $(3.82)$ & $(1.44)$ \\
$N$ & $0.543^{* * *}$ & $0.071^{* * *}$ & $0.614^{* * *}$ & $0.359^{* * *}$ \\
$N$ & $(35.95)$ & $(8.87)$ & $(35.37)$ & $(9.88)$ \\
$R^{2}$ & 726 & 726 & 726 & 726 \\
$F$ & 0.627 & 0.092 & 0.619 & 0.157 \\
Ftest $\left(u_{i}=0\right)$ & $1292.36^{* * *}$ & $78.59^{* * *}$ & $1250.97^{* * *}$ & $97.29^{* * *}$ \\
Chow test & 1.29 & 1.03 & 1.20 & 0.98 \\
B-P LM test & 1.06 & 1.34 & 1.18 & 1.45 \\
\hline
\end{tabular}

This table displays results for OLS estimations of the equations in specifications (3), (4) and (5). $t$-statistics are shown in parentheses *** $p<0.01$

Table 5 The estimators for pecking order model according to crisis period classification

\begin{tabular}{|c|c|c|c|c|c|c|c|c|c|}
\hline \multirow[t]{2}{*}{ Variables } & \multicolumn{3}{|l|}{ Pre-crisis } & \multicolumn{3}{|l|}{ Crisis } & \multicolumn{3}{|l|}{ Post-crisis } \\
\hline & Net debt & Net Sukuk & Net equity & Net debt & Net Sukuk & Net equity & Net debt & Net Sukuk & Net equity \\
\hline$a$ & $\begin{array}{l}0.001 \\
(0.05)\end{array}$ & $\begin{array}{l}0.001 \\
(0.06)\end{array}$ & $\begin{array}{l}-0.007 \\
(-0.22)\end{array}$ & $\begin{array}{l}0.017^{* * *} \\
(3.47)\end{array}$ & $\begin{array}{l}0.002 \\
(0.71)\end{array}$ & $\begin{array}{l}0.013^{* *} \\
(2.16)\end{array}$ & $\begin{array}{l}0.005^{* * *} \\
(3.05)\end{array}$ & $\begin{array}{l}0.001 \\
(1.06)\end{array}$ & $\begin{array}{l}0.010^{* * *} \\
(5.21)\end{array}$ \\
\hline$\beta$ & $\begin{array}{l}0.529 * * * \\
(17.69)\end{array}$ & $\begin{array}{l}0.083^{* * *} \\
(6.96)\end{array}$ & $\begin{array}{l}0.376^{* * *} \\
(4.72)\end{array}$ & $\begin{array}{l}0.396^{* * *} \\
(13.55)\end{array}$ & $\begin{array}{l}0.059^{* * *} \\
(3.30)\end{array}$ & $\begin{array}{l}0.424^{* * *} \\
(7.77)\end{array}$ & $\begin{array}{l}0.551^{* * *} \\
(27.82)\end{array}$ & $\begin{array}{l}0.023^{* * *} \\
(5.25)\end{array}$ & $\begin{array}{l}0.225^{* * *} \\
(9.95)\end{array}$ \\
\hline$N$ & 132 & 132 & 132 & 132 & 132 & 132 & 462 & 462 & 462 \\
\hline$R^{2}$ & 0.692 & 0.254 & 0.084 & 0.568 & 0.066 & 0.299 & 0.612 & 0.046 & 0.167 \\
\hline$F$ & $312.8^{* * *}$ & $48.46^{* * *}$ & $7.42^{* * *}$ & $183.5^{* * *}$ & $10.86^{* * *}$ & $60.42^{* * *}$ & $773.8^{* * *}$ & $9.08^{* * *}$ & $98.99 * * *$ \\
\hline$F$ test & 1.01 & 0.62 & 1.01 & 1.48 & 0.91 & 0.84 & 1.57 & 1.09 & 1.28 \\
\hline Chow test & 1.17 & 1.42 & 1.33 & 1.27 & 1.36 & 1.09 & 1.22 & 1.54 & 1.13 \\
\hline$B-P$ test & 0.72 & 0.93 & 0.86 & 0.81 & 0.89 & 0.66 & 0.79 & 0.98 & 0.69 \\
\hline
\end{tabular}

This table displays results for OLS estimations of the equations in specifications (3), (4) and (5) according to crisis period classifications. $t$-statistics are shown in parentheses

${ }^{* * *} p<0.01,{ }^{* *} p<0.05$

If the firm needs more funds but cannot use debtbased instruments due to the debt-ratio constraint, ${ }^{2}$ then it moves to equity financing. Regarding net equity issued, the results show a positive and significant coefficient (0.359) associated with financial deficit. Looking at these results in comparison with those in other developing countries, Allini et al. [2] find a coefficient of 0.519 in Egypt, and Chen et al. [8] find it to be 0.675 in Taiwan.

As a last alternative to finance deficit, Islamic firms issue $S u k u k$. The results reveal a positive low coefficient (0.071) of financial deficit on net Sukuk issued. This can be explained by the under-development of Sukuk market in KSA. According to Alshamrani [4], the Sukuk market

\footnotetext{
2 The debt-ratio constraint maintains that it cannot exceed the ratio of tangible assets to total assets [1].
}

in KSA is new and immature; the first issuance of Sukuk was in 2004. The author emphasizes that the issuance of Sukuk in Saudi Arabia is suffering from heavy regulation and supervision drawbacks, which need to be identified in order to resolve the problems of regulation and insufficiency of supervision. This argument aligns with Alnoria and Alqahtani [3], who state that because of its complexity, firms are discouraged from issuing a Sukuk or at least making it their first option.

In sum, capital choice decision of Islamic-compliant firms seems to follow a modified POT, in which firms rely on retained profit, followed by sale-based instrument (Murabahah, Ijara), then equity, with Sukuk as the last option.

We also ran tests using deficits, debt issues, Sukuk issues and equity issues according to crisis periods. The results presented in Table 5 support the same modified 
Table 6 Correlation matrix and VIF values

\begin{tabular}{llllll}
\hline & TAN & MTB & LS & PRF & CDEF \\
\hline TANG & 1 & & & & VIF \\
MTB & -0.005 & 1 & & & 1.13 \\
LS & 0.249 & -0.205 & 1 & 1 & 1.19 \\
PRF & -0.180 & 0.307 & 0.068 & -0.113 & 1.17 \\
CDEF & 0.095 & -0.022 & 0.084 & 1.21 \\
\hline
\end{tabular}

Table 7 Results of the unit root tests

\begin{tabular}{|c|c|c|c|c|c|}
\hline \multirow[t]{2}{*}{ Variables } & \multicolumn{2}{|l|}{ ADF } & \multicolumn{2}{|l|}{ PP } & \multirow{2}{*}{$\begin{array}{l}\text { Stationarity } \\
\text { status }\end{array}$} \\
\hline & Level $(I(0))$ & First difference $(I(1))$ & Level $(I(0))$ & First difference $(/(1))$ & \\
\hline BBD & $102.058^{* * *}$ & $169.252^{* * *}$ & $85.763^{* * *}$ & $237.423^{* * *}$ & $I(0)$ \\
\hline $\mathrm{MBD}$ & $100.865^{* * *}$ & $208.513^{* * *}$ & $100.168^{* * *}$ & $269.756^{* * *}$ & $/(0)$ \\
\hline TAN & $89.743^{* * *}$ & $149.254^{* * *}$ & $73.016^{* *}$ & $193.654^{* * *}$ & $/(0)$ \\
\hline MTB & $91.907^{* * *}$ & $168.772^{* * *}$ & $97.483^{* * *}$ & $192.896^{* * *}$ & $I(0)$ \\
\hline LS & $93.421^{* * *}$ & $232.425^{* * *}$ & $83.147^{* *}$ & $289.452^{* * *}$ & $/(0)$ \\
\hline PRF & $111.546^{* * *}$ & $187.472^{* * *}$ & $86.471^{* * *}$ & $234.912^{* * *}$ & $/(0)$ \\
\hline CDEF & $124.253^{* * *}$ & $272.857^{* * *}$ & $125.704^{* * *}$ & $396.453^{* * *}$ & $/(0)$ \\
\hline
\end{tabular}

This table displays the results of ADF test and PP test

*** $p<0.01,{ }^{* *} p<0.05$

POT in the pre and post-crisis only. Financial deficit is financed by sale-based instrument (Murabahah, Ijara), then equity, and lastly by Sukuk. However, the POT is highly violated in the crisis period. The results displayed in Table 5 show less reliance of firms on debt issuance in the crisis period. KSA firms seem more reliant on equity, then on sale-based instrument and on Sukuk as last alternative. Hence, KSA firms that are willing to expand often find it difficult to obtain financing from financial institutions in the crisis period and are thus credit constrained. This constitutes the "financing-gap" encountered by firms and this gap is more prevalent in crisis period. The financial crisis arguably provides a shock to the supply of external financing resulting in lending contraction for banking system. Consequently, firms will experience a fall in corporate borrowing and capital expenditures. This reflects in less leverage ratios in the crisis period. This argument aligns with Dewally and Shao [11] who suggest that the liquidity shocks to the short-term funding markets impose liquidity constraints to banks, resulting in lending cut and changes in the capital structure of corporations.

\section{Tests of conventional leverage regressions}

The next test of the theory is to see how the financing deficit works when added to a conventional leverage regression. If the pecking order hypothesis is true, the inclusion of the financing deficit variable would increase the $R^{2}$ considerably (relative to running the regression without this variable) because the financing deficit should be the most important variable in the equation. In addition, we would expect that adding the financing deficit variable should render the effects of the other conventional explanatory variables insignificant.

First, we carry out two tests to check the existence of multicollinearity among the explanatory variables: the pairwise correlation matrix among the explanatory variables and the variance inflation factor (VIF). According to Kennedy [20], a multicollinearity problem arises if the correlation among the independent variables is greater than or equal to 0.80 . As shown in Table 6, the Pearson correlation coefficients appear to be relatively low and there is no correlation between the variables that reach 0.8 . The low magnitude of correlations among the explanatory variables indicates that multicollinearity is not a problem for the sample.

Furthermore, a VIF test was performed to examine the existence of multicollinearity. As highlighted in Table 6, all VIF values of explanatory variables are less than 4 , supporting the previous conclusion of the absence of multicollinearity problem in the data. According to O'Brien [31], a VIF value exceeding 4 warrants further investigations, while a VIF value exceeding 10 is a sign of serious multicollinearity requiring correction. 
Table 8 Leverage regressions with conventional variables and cumulative financial deficit for the full sample

\begin{tabular}{|c|c|c|c|c|}
\hline \multirow[t]{2}{*}{ Variables } & \multicolumn{2}{|c|}{ Book-based debt } & \multicolumn{2}{|c|}{ Market-based debt } \\
\hline & (1) & $(2)$ & (3) & (4) \\
\hline Constant & $\begin{array}{l}-2.858^{* * *} \\
(-7.43)\end{array}$ & $\begin{array}{l}-2.815^{* * *} \\
(-7.71)\end{array}$ & $\begin{array}{l}-1.342^{* *} \\
(-2.41)\end{array}$ & $\begin{array}{l}-1.290^{* *} \\
(-2.44)\end{array}$ \\
\hline TAN & $\begin{array}{l}0.553^{* * *} \\
(5.88)\end{array}$ & $\begin{array}{l}0.552^{* * *} \\
(6.00)\end{array}$ & $\begin{array}{l}0.361^{* *} \\
(1.97)\end{array}$ & $\begin{array}{l}0.333^{*} \\
(1.88)\end{array}$ \\
\hline MTB & $\begin{array}{l}-0.036^{* *} \\
(-2.29)\end{array}$ & $\begin{array}{l}-0.036^{* * *} \\
(-2.32)\end{array}$ & $\begin{array}{l}-0.123^{* * *} \\
(-3.61)\end{array}$ & $\begin{array}{l}-0.124^{* * *} \\
(-3.74)\end{array}$ \\
\hline LS & $\begin{array}{l}0.313^{* * *} \\
(7.57)\end{array}$ & $\begin{array}{l}0.308^{* * *} \\
(7.84)\end{array}$ & $\begin{array}{l}0.177^{* * *} \\
(2.96)\end{array}$ & $\begin{array}{l}0.171^{* * *} \\
(3.02)\end{array}$ \\
\hline PRF & $\begin{array}{l}-0.492^{* * *} \\
(-3.27)\end{array}$ & $\begin{array}{l}-0.484^{* * *} \\
(-3.26)\end{array}$ & $\begin{array}{l}-0.254 \\
(-0.76)\end{array}$ & $\begin{array}{l}-0.192 \\
(-0.59)\end{array}$ \\
\hline CDEF & & $\begin{array}{l}0.370^{* * *} \\
(4.55)\end{array}$ & & $\begin{array}{l}0.932^{* * *} \\
(4.45)\end{array}$ \\
\hline$R^{2}$ & 0.398 & 0.417 & 0.326 & 0.369 \\
\hline N & 726 & 726 & 726 & 726 \\
\hline$F$ test $\left(u_{i}=0\right)$ & $14.30^{* * *}$ & $14.09^{* * *}$ & $2.99 * * *$ & $2.87^{* * *}$ \\
\hline Chow test & $17.86^{* * *}$ & $21.07^{* * *}$ & $24.93^{* * *}$ & $31.05^{* * *}$ \\
\hline$B-P$ LM test & $1089.42^{* * *}$ & $1044.40^{* * *}$ & $74.60^{* * *}$ & $66.16^{* * *}$ \\
\hline Hausman test & 6.06 & 7.35 & 8.32 & 11.08 \\
\hline Wald $x^{2}$ & $158.51^{* * *}$ & $188.46^{* * *}$ & $37.84^{* * *}$ & $61.76^{* * *}$ \\
\hline
\end{tabular}

This table reports the results of Eq. (6). $t$-statistics are shown in parentheses. ${ }^{* * *} p<0.01,{ }^{* *} p<0.05$ and ${ }^{*} p<0.1$
Second, this study carried out two root tests on all the variables in order to confirm that all variables are stationary. In particular, we employed the augmented Dickey and Fuller [12] test (ADF) and the Phillips and Perron [32] test (PP). The results reported in Table 7 indicate that all variables are stationary at the first difference. Therefore, our models using the first difference operator are appropriate for avoiding spurious estimates.

Third, the selection of the appropriate model was made following four different tests developed by Baltagi [5], Chow [10], Hausman [16], and Breusch and Pagan [7]. The results reported in Tables 8 and 9 reveal that the individual effect models (fixed effects and the random effects) are the most appropriate. The statistics of $F$ test, Chow test and Breusch and Pagan test are significant in all regressions. Thus, the Hausman [16] specification test was conducted to decide between the fixed effect model and the random effect model. The results show that all values of Hausman test are insignificant implying that the random effects model is preferred to the fixed effects model.

Table 8 provides the results for the full sample using Book-based debt and Market-based debt as independent variables. The conventional regressions before the deficit variable addition are provided in columns (1) and (3). The

Table 9 Leverage regressions according to crisis period classification

\begin{tabular}{|c|c|c|c|c|c|c|}
\hline Variables & Pre-crisis & & Crisis & & Post-crisis & \\
\hline Constant & $\begin{array}{l}3.095^{* * *} \\
(-4.84)\end{array}$ & $\begin{array}{l}1.816^{* * *} \\
(-3.69)\end{array}$ & $\begin{array}{l}-2.677^{* * *} \\
(-4.80)\end{array}$ & $\begin{array}{l}-2.628^{* * *} \\
(-4.66)\end{array}$ & $\begin{array}{l}-2.692^{* * *} \\
(-5.27)\end{array}$ & $\begin{array}{l}-2.642^{* * *} \\
(-5.17)\end{array}$ \\
\hline TAN & $\begin{array}{l}0.285^{*} \\
(1.71)\end{array}$ & $\begin{array}{l}0.199 \\
(1.50)\end{array}$ & $\begin{array}{l}0.531^{* * *} \\
(3.08)\end{array}$ & $\begin{array}{l}0.546^{* * *} \\
(3.12)\end{array}$ & $\begin{array}{l}0.768^{* * *} \\
(5.84)\end{array}$ & $\begin{array}{l}0.828^{* * *} \\
(6.41)\end{array}$ \\
\hline MTB & $\begin{array}{l}-0.064^{*} \\
(-1.73)\end{array}$ & $\begin{array}{l}-0.045^{*} \\
(-1.64)\end{array}$ & $\begin{array}{l}-0.045 \\
(-1.37)\end{array}$ & $\begin{array}{l}-0.047 \\
(-1.41)\end{array}$ & $\begin{array}{l}-0.029 \\
(-1.56)\end{array}$ & $\begin{array}{l}-0.027 \\
(-1.49)\end{array}$ \\
\hline LS & $\begin{array}{l}0.369^{* * *} \\
(5.26)\end{array}$ & $\begin{array}{l}0.219^{* * *} \\
(4.02)\end{array}$ & $\begin{array}{l}0.298^{* * *} \\
(4.95)\end{array}$ & $\begin{array}{l}0.291^{* * *} \\
(4.77)\end{array}$ & $\begin{array}{l}0.278^{* * *} \\
(5.12)\end{array}$ & $\begin{array}{l}0.269^{* * *} \\
(4.95)\end{array}$ \\
\hline PRF & $\begin{array}{l}-1.265^{* * *} \\
(-2.85)\end{array}$ & $\begin{array}{l}-0.695^{* *} \\
(-1.98)\end{array}$ & $\begin{array}{l}-0.283 \\
(-1.02)\end{array}$ & $\begin{array}{l}-0.257 \\
(-0.91)\end{array}$ & $\begin{array}{l}-0.257^{*} \\
(-1.71)\end{array}$ & $\begin{array}{l}-0.284^{*} \\
(-1.95)\end{array}$ \\
\hline CDEF & & $\begin{array}{l}1.141^{* * *} \\
(7.67)\end{array}$ & & $\begin{array}{l}0.045 \\
(0.61)\end{array}$ & & $\begin{array}{l}0.583^{* * *} \\
(5.07)\end{array}$ \\
\hline $\mathrm{R}^{2}$ & 0.303 & 0.565 & 0.371 & 0.372 & 0.322 & 0.312 \\
\hline N & 132 & 132 & 132 & 132 & 462 & 462 \\
\hline$F$ test $\left(u_{i}=0\right)$ & $6.87^{* * *}$ & $4.71^{* * *}$ & $22.97^{* * *}$ & $22.60^{* * *}$ & $19.42^{* * *}$ & $20.74^{* * *}$ \\
\hline Chow test & $22.83^{* * *}$ & $19.24^{* * *}$ & $17.07^{* * *}$ & $14.87^{* * *}$ & $21.98^{* * *}$ & $25.02^{* * *}$ \\
\hline$B-P$ LM test & $26.96^{* * *}$ & $13.86^{* * *}$ & $56.29 * * *$ & $56.19^{* * *}$ & $718.90^{* * *}$ & $745.19^{* * *}$ \\
\hline Hausman test & 4.78 & 3.43 & 1.12 & 0.49 & 2.48 & 2.83 \\
\hline Wald $x^{2}$ & $49.72^{* * *}$ & $131.56^{* * *}$ & $50.89^{* * *}$ & $51.05^{* * *}$ & $86.45^{* * *}$ & $115.06^{* * *}$ \\
\hline
\end{tabular}

This table reports the results of Eq. (6) for the following subsamples: pre-crisis, crisis and post-crisis periods. $t$-statistics are shown in parentheses. ${ }^{* * *} p<0.01$, ${ }^{* *} p<0.05$ and ${ }^{*} p<0.1$ 
estimated coefficients on tangibility, the market-to-book ratio, firm size and profitability have the usual signs. The results show that the tangibility is found to be significant and positively related to both leverage measures which is inconsistent with the POT prediction. As debt has to be asset-backed in firms operating under Islamic principles, leverage will increase with the increase in tangible assets.

The coefficient signs are negative on the market-tobook ratio for both leverage measures. Like conventional firms, debt instruments in Islamic-compliant firms have high distress costs (see Table 1). Consequently, a negative relationship between firms' future opportunities and their leverage choice will be established because growth firms are predicted to lose more of their value when they become financially distressed [14].

The coefficients associated with the size variable are positive and significant on both leverage measures consistent with the findings of Frank and Goyal [14]. In term of information asymmetries, large firms are expected to convey more information than small firms. This facilitates their access to the credit market which enhances their debt capacity. The results reveal that profitability is negatively related to both leverage measures, which is consistent with the POT and in line with most empirical research (e.g., $[3,14])$.

In columns (2) and (4), both leverage regressions are estimated with financing deficit as an additional explanatory variable. The results show that the cumulative financing deficit added about $2 \%$ and $4 \%$ to the explanatory power of the Book-based debt and Market-based debt regressions, respectively. Further, the results indicate that the addition of the deficit variable to the regression does not result in an effect on the magnitudes and significance of the coefficients on the conventional variables. However, the financing deficit is empirically relevant. Thus, the cumulative financing deficit works well in both leverage regressions, although the POT is rejected. This reflects that the current capital structure of Islamic-compliant firms in KSA is strongly related to cumulative financing deficit.

This result aligns with previous studies including Chen et al. [8] who find that the introduction of the cumulative financial deficit in leverage specifications did not have much influence on the significance of other conventional variables' coefficients although the financing deficit is empirically significant. Similarly, Allini et al. [2] show that the inclusion of the cumulative financial deficit in leverage regressions did not affect the significance of the other conventional variables. Moreover, there is no gain in terms of the explanatory power of the regressions.
The same tests are done considering crisis period classification. Table 9 provides empirical results. To save space, we only report the results using the Bookbased debt regression. Except market-to book ratio, most variables show the similar sign and significance to the all-firms' sample. The coefficient associated with MTB variable is not significant in crisis and postcrisis periods.

Further, the results indicate that the inclusion of the cumulative financing deficit did not influence the signs, magnitudes and significance of the coefficients of conventional factors. As seen in Table 9, the coefficient of the cumulative financing deficit is significant in all regression except in crisis period. This aligns with the original results about the reject of the POT in KSA Islamic firms. In addition, the findings reflect the financial behavior disturbance of KSA firms during the crisis period.

\section{Conclusion}

The objective of this study was to investigate whether the POT is an accurate means to describe the incremental financing practices by firms operating under Islamic principles.

Employing panel data analysis, this study first examines how well Islamic financial instruments track the financing deficit. The results show that sale-based instruments (Murabahah, Ijara) track the financial deficit much closer as they are cheaper than other alternatives and they do not dilute ownership. If the firm needs more funds but cannot use debt-based instruments due to the debt-ratio constraint, then it moves to equity financing. As a last alternative to finance deficit, Islamic-compliant firms issue Sukuk. This can be explained by the under-development of Sukuk market in KSA. Further, the results reveal high violation of the POT in the crisis period. Islamic-compliant firms seem more reliant on equity, then on sale-based instrument and on Sukuk as last alternative. Due to credit constraints in the crisis period, debt financing is less preferred and more equity capital financing is used.

Next, the study findings indicate that the inclusion of the cumulative financing deficit does not wipe out the effects of conventional variables, although it is empirically significant. This provides no support for the POT attempts by KSA Islamic-compliant firms.

Overall, it seems that the issuance activity of Islamiccompliant firms is more closely to the need of funds instead of adhering to a hierarchy of financing sources.

There are several important areas where this study makes original contributions to the related literature. First, this research extends literature on capital structure. It highlights the capital structure choice of firms operating 
under Islamic principles. Second, this research focuses on the capital structure of Islamic-compliant firms in KSA, which has not been previously tackled by any research effort. Third, the present paper sheds light on the impact of the global financial crisis on Islamic banking, and therefore, on the Islamic firms' capital structure choice. Finally, the findings will contribute significantly to the body of knowledge as well as to practitioners and to firms that would like to operate under Islamic principles.

Several implications can be derived from the study results. First, due to the lack of legislative and regulatory framework of Sukuk issuance, it is recommended to update the present regulations for the offering and issuance of securities in KSA in order to cover Sukuk. In this regard, policymakers, bankers and standard-setting organizations should undertake more collective work to simplify the process of issuing Islamic financial instruments, including Sukuk. Second, the Saudi government has to encourage the private sector to be more innovative in developing products and services that are in line with Sharia principles. Finally, to attract investors, the Saudi Capital Market Authority (CMA) has to encourage transaction, efficiency and liquidity of Islamic financial instruments.

The paper identifies some areas where further research on topics related to capital structure of Islamic-compliant firms is needed. The failure of the POT to explain KSA firms' financing choices strongly pushed researchers to test the market timing theory for the Saudi stock market. Further, scholars could re-examine the trade-off theory in the absence of interest tax shield as in an Islamic economy.

\begin{abstract}
Abbreviations
AAOIFI: Accounting and Auditing Organization for Islamic Financial Institutions; CMA: Capital Market Authority; GCC: Gulf Cooperation Council; KSA: Kingdom of Saudi Arabia; NSC: Non-Sharia-Compliant; OLS: Ordinary least squares; PLS: Profit and loss sharing; POT: Pecking order theory; SAMA: Saudi Monetary Authority; SC: Sharia-compliant; VIF: Variance inflation factor.
\end{abstract}

\section{Acknowledgements}

Not applicable.

\section{Authors' contributions}

MG reviewed the literature, analyzed, interpreted and discussed the results. $\mathrm{He}$ is the only contributor in writing the manuscript. The author read and approved the final manuscript.

\section{Funding}

There is no source of funding.

\section{Availability of data and materials}

The datasets generated and/or analyzed during the current study are available in the Argaam web site repository, www.argaam.com.

\section{Competing interests}

The authors declare that they have no competing interests.

Received: 28 November 2019 Accepted: 2 November 2020 Published: 26 November 2020

\section{References}

1. Ahmed H (2007) Issues in Islamic corporate finance: capital structure in firms. IRTI research paper series no. 70, Jeddah, Saudi Arabia

2. Allini A, Rakha S, McMillan DG, Caldarelli A (2018) Pecking order and market timing theory in emerging markets: the case of Egyptian firms. Res Int Bus Finance 44:297-308

3. Alnoria F, Alqahtani F (2019) Capital structure and speed of adjustment in non-financial firms: does sharia compliance matter? Evidence from Saudi Arabia. Emerg Mark Rev 39:50-67

4. Alshamrani $A$ (2014) Sukuk issuance and its regulatory framework in Saudi Arabia. J Islam Bank Finance 2(1):305-333

5. Baltagi BH (1995) Econometric analysis of panel data. Wiley, New York

6. Booth L, Aivazian V, Demirguc-Kunt A, Maksimovic V (2001) Capital structures in developing countries. J Finance 56(1):87-130

7. Breusch S, Pagan R (1980) The Lagrange multiplier test and its applications to model specification in econometrics. Rev Econ Stud 47(1):239-253

8. Chen DH, Chen CD, Chen J, Huang YF (2013) Panel data analyses of the pecking order theory and the market timing theory of capital structure in Taiwan. Int Rev Econ Finance 27:1-13

9. Chirinko RS, Singha AR (2000) Testing static tradeoff against pecking order models of capital structure: a critical comment. J Financ Econ 58(3):417-425

10. Chow GC (1960) Tests of equality between sets of coefficients in two linear regressions. Econometrica 28:591

11. Dewally M, Shao Y (2014) Liquidity crisis, relationship lending and corporate finance. J Bank Finance 39:223-239

12. Dickey DA, Fuller WA (1981) Likelihood ratio statistics for autoregressive time series with a unit root. Econometrica 49:1057

13. Fama EF, French KR (2005) Financing decisions: who issues stock? J Financ Econ 76(3):549-582

14. Frank MZ, Goyal VK (2003) Testing the pecking order theory of capital structure. J Financ Econ 67(2):217-248

15. Gunn T, Shackman J (2014) A comparative analysis of the implications of the Islamic religion on corporate capital structures of firms in emerging market countries. Int J Islam Middle East Finance Manag 7(3):277-287

16. Hausman J (1978) Specification tests in econometrics. Econometrica 46:1251-1271

17. Ibrahim MH (2015) Issues in Islamic banking and finance: Islamic banks, Shari'ah-compliant investment and sukuk. Pac Basin Finance J 34(4):185-191

18. Ismal R (2014) Assessing the gold Murabahah in Islamic banking. Int J Commer Manag 24(4):367-382

19. Kayed RN (2012) The entrepreneurial role of profit-and-loss sharing modes of finance: theory and practice. Int J Islam Middle East Finance Manag 5(3):203-228

20. Kennedy P (1985) A guide to econometrics. Massachusetts Institute of Technology Press, Cambridge

21. Klein PO, Weill L (2016) Why do companies issue Sukuk? Rev Financ Econ 31:26-33

22. Komera S, Lukose J (2015) Capital structure choice, information asymmetry, and debt capacity: evidence from India. J Econ Finance 39(4):807-823

23. Lemmon ML, Roberts MR, Zender JF (2008) Back to the beginning: persistence and the cross-section of corporate capital structure. J Finance 63(4):1575-1608

24. Miah MD, Suzuki Y (2020) Murabaha syndrome of Islamic banks: a paradox or product of the system? I Islam Account Bus Res 11(7):1363-1378

25. Minhat M, Dzolkarnaini N (2016) Which firms use Islamic financing? Econ Lett 150:15-17

26. Modigliani F, Miller M (1958) The cost of capital corporation finance, and the theory of investment. Am Econ Rev 48(3):261-297

27. Moradi A, Paulet E (2019) The firm-specific determinants of capital structure - An empirical analysis of firms before and during the Euro Crisis. Res Int Bus Finance 47(1):150-161

28. Myers SC (1984) The capital structure puzzle. J Finance 39(3):575-592

29. Myers SC, Majluf NS (1984) Corporate financing and investment decisions when firms have information that investors do not have. J Financ Econ 13(2):187-221 
30. Naz I, Shah SMA, Kutan AM (2017) Do managers of sharia: compliant firms have distinctive financial styles? J Int Financ Mark Inst Money 46:174-187

31. O'Brien RM (2007) A caution regarding rules of thumb for variance inflation factors. Qual Quant 41(5):673-690

32. Phillips PC, Perron $P$ (1988) Testing for a unit root in time series regression. Biometrika 75:335

33. Sakti MR, Saiti B, Akhtar T (2017) Capital structure of Islamic banks: a critical review of theoretical and empirical research. Qual Res Financ Mark 9(3):292-308

34. Shyam-Sunder L, Myers S (1999) Testing static trade-off against pecking order models of capital structure. J Financ Econ 51(2):219-244

35. Smolo E, Mirakhor A (2010) The global financial crisis and its implications for the Islamic financial industry. Int J Islam Middle East Finance Manag 3(4):372-385
36. Yildirim R, Masih M, Bacha Ol (2018) Determinants of capital structure: evidence from Shari'ah compliant and non-compliant firms. Pac Basin Finance J 51:198-219

37. Zolfaghari P (2017) An Introduction to Islamic Securities (Sukuk). Uppsala faculty of law working paper 2017:2

\section{Publisher's Note}

Springer Nature remains neutral with regard to jurisdictional claims in published maps and institutional affiliations.

\section{Submit your manuscript to a SpringerOpen ${ }^{\circ}$ journal and benefit from:}

- Convenient online submission

- Rigorous peer review

- Open access: articles freely available online

- High visibility within the field

Retaining the copyright to your article

Submit your next manuscript at $\boldsymbol{\nabla}$ springeropen.com 